\author{
يهنهبندى كمى سطح زمين به وسيله ضرايب كمى در راستاى مكانيابى بهينه \\ يخش سيلاب (مطالعه موردى حوضه آبخيز گربايخان فسا) \\ صديقه ابراهيميان'، محمد نهتانى ا*و حسين صادقى مزيدى

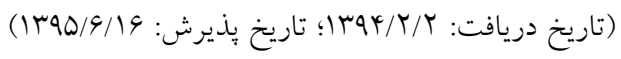

جكيده

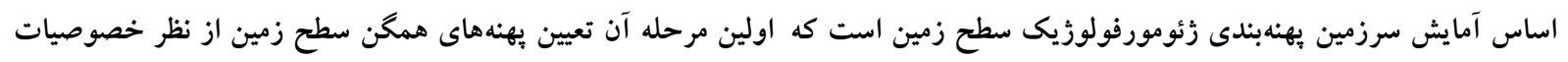

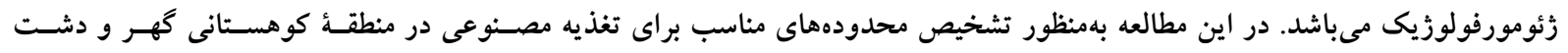

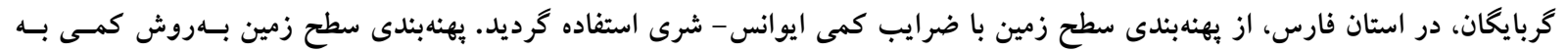

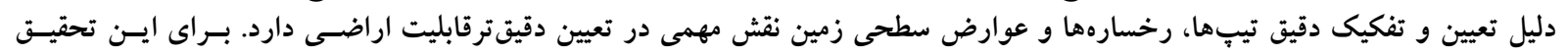

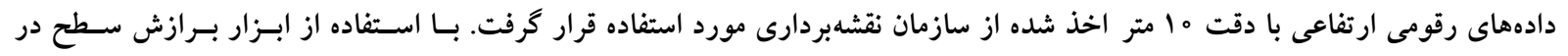

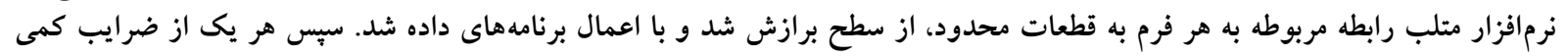

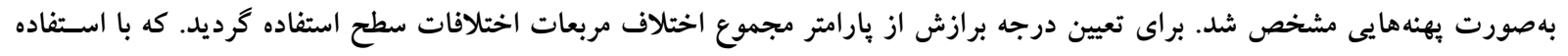

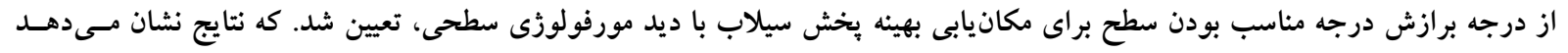

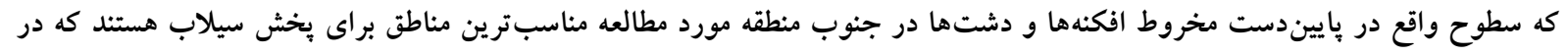

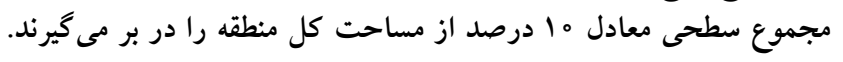

وازمهاى كليدى: ايوانس - شرى، بهنهبندى كمى زئومورفولوزيك، بخشسيلاب، كربايخان

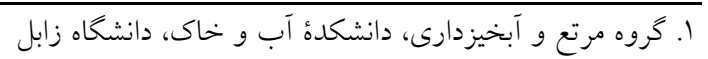

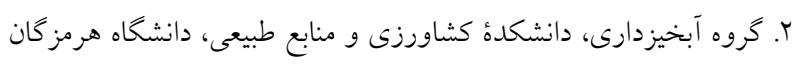

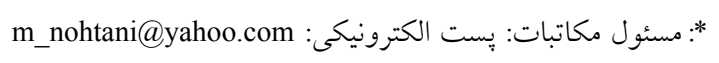


و اهميت توجه به آن در بيشتر استانهاى كشـور از جملـه اسـتان مقدمه فارس از اولويت بسيار زيادى برخوردار است (11). در اين راستا تشخيص دقيق عوارض سطح زمين اهميت بسيار زياد در شناسايى مناطق مناسب بخخش سـيلاب دارد. در مـــيريت سـطح زمسين بـهـ خصوص در مناطق شكنندهاى مانند مناطق بيابانى، بيهنهبندى سطح زمين از نظر زئومورفولوزى ضروزى به نظر مىرسد. شكل سـطح زمين ساختار يبيجيدهاى از فرمهاى مختلف در مقياس هاى مختلف

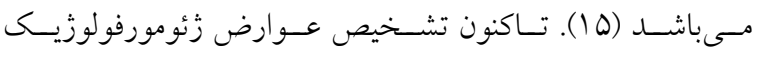
بهصورت كيفى و براساس بارامترهاى توصيفى زمين مانند ارتفـاع،

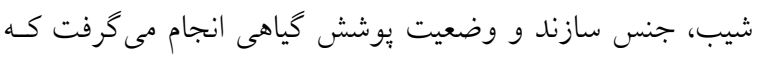

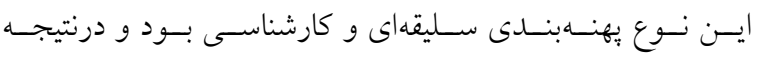
بهنهبندىهاى بهدست آمده توسط اشخاص مختلف يكسان نبوده و تشخيص، رخسارههاى با مرزهاى دقيق را غيـرممكن مسىسـاخت

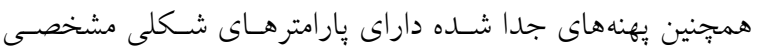
براى مقايسه با ساير مناطق نيستند كه از ميزان دقت كاسته مىشود،

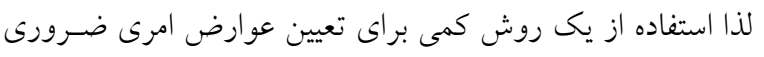
مىباشد (r). در مطالعات بهروش كيفى مشكلات اساسى كـه در اين راستا وجود دارد. اولين مشـكل، بيشـتر خصوصسيات شـناخته

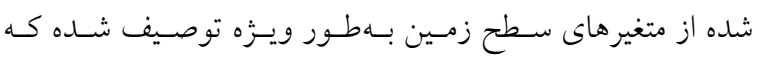

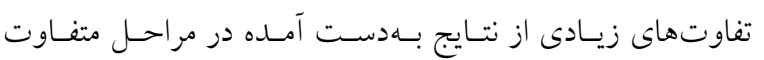

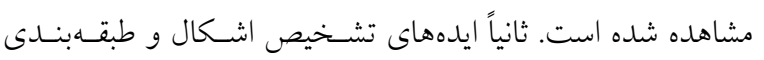

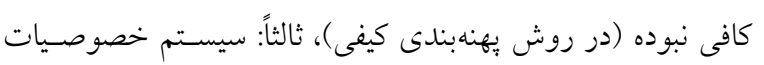

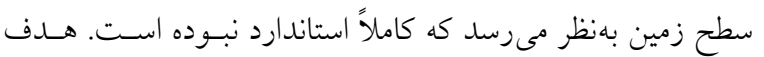
عمده از اين مطالعات اين است كه ما جزئيات مهم را براى متغيرها و اصول مهمى كه جندين خصوصيات متفاوت كه به ويز گیىهـاى سطح زمين بستخى دارد را توصيف مى كند. براى رفع ايسن مشـكل بهنهابندى جديدى كه بهزهنبندى كمى يا روشى است كه با استفاده از دادههاى انحنا و مشتقات مختلف ارتفاع و شيب و با به كار كيرى نرمافزارها و روشهاى خودكار تعريف شــده و براسـاس اعـداد و

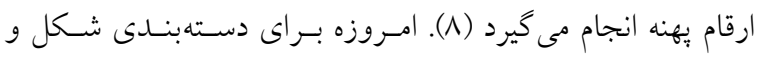
عوارض سطح زمين از ضرايب و بارامترهاى كمى بهدست آمده از

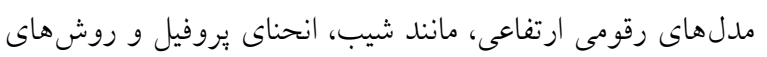
با توجه به شر ايط اقليمسى خشـك و نيمسه خشـك ايـران و بــروز مشكلات عديدهاى جِون كـم آبسى در بسـيارى از منـاطق كشـور،

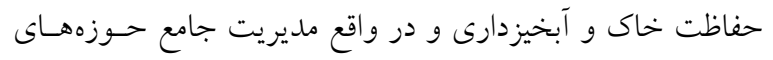
آبخيز از سازندهترين راهكارها براى مقابله با خشكسالى است (ب). راهبرد اساسى كنترل سيلاب به تغذيه سفرهاى آب كمك مى كند و

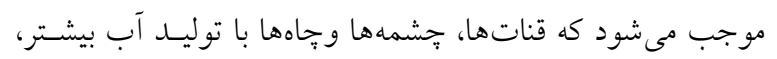
بستر مناسبى را فراهم آورند تا زمينهاى كشاورزى بيشترى به زير كشت آبى رفته و توليد محصولات غذايى بيشتر شود. اين شيوه به

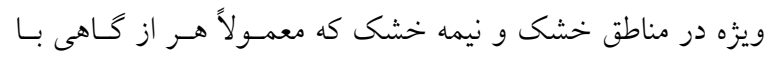
جارى شدن سيلابهاى با دبى لحظهاى بالا، مواجه هستند، بسـيار راهخشا است يكى از روشهاى مناسب جهـت استحصـال آب در

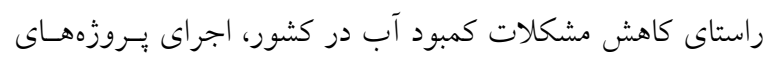

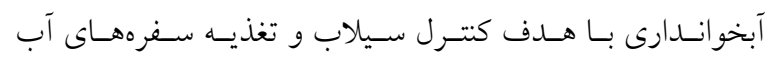
زيرزمينى است. يكى از روشهاى استحصال آب، بهــــبــردارى از

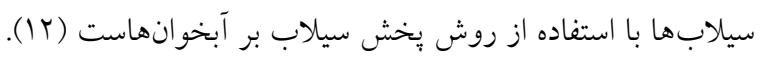

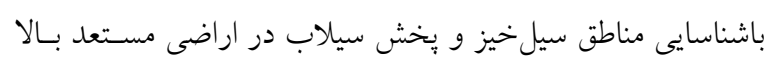

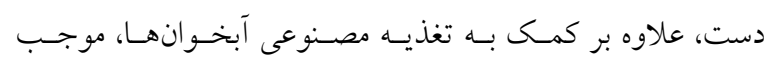
افزايش كيفيت و حاصل خيزى خاى هم مىشود (9). كشور ايسران با عدم توازن توزيع زمانى و مكانى آب مواجه است. حدود نيمسى از جمعيت كشـور در منساطق مركـزى، شـرقى و جنـوبى زنسـدى مى كنند كه تنها بـه مبا درصـد منـابع آبسى دسترسى دارنــ (11). افزايش جمعيت طى جهل سال اخير موجب كـاهش سـرانهُ منـابع آبى تجديديذير از V هزار متر مكعب به Y هزار متر مكعب كرديده

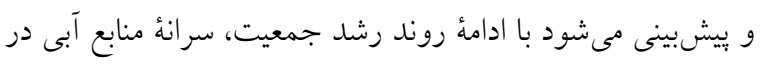

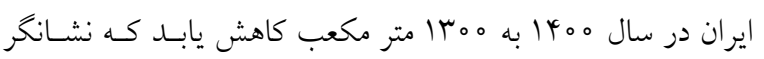

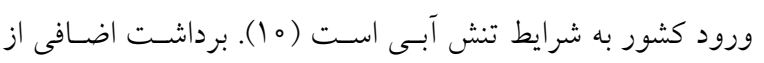

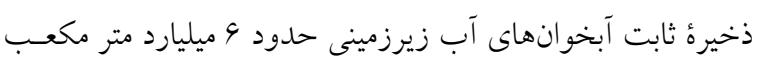

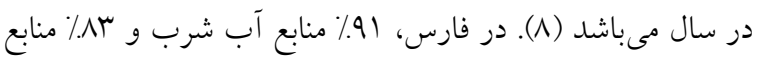
آب كشاورزى از منابع زيرزمينى تأمين مىشود (ه ا). لذا بـه دليـل خشكسالى هاى طولانى مدت و عـدم تعـادل بــين ميـزان تغذيـه و برداشت از سفرههاى آب زيرزمينى، مىتوان كفت كه موضوع آب 
دارد (Yo). در يكى روش شباهت داخلى و همخگن بودن خود بهنـه

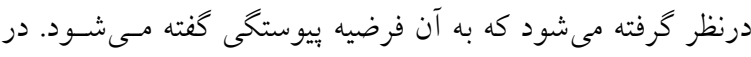

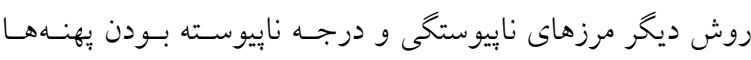

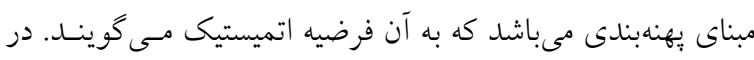

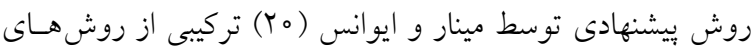

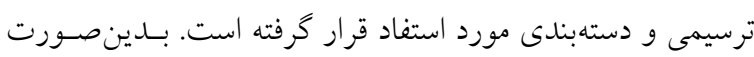

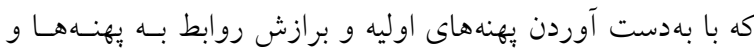

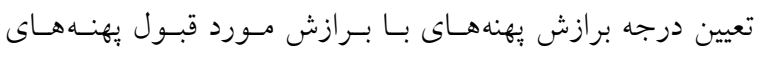

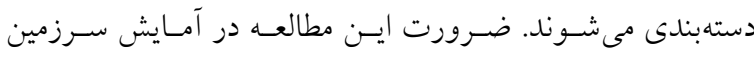

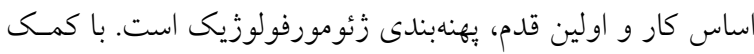

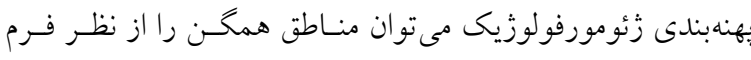

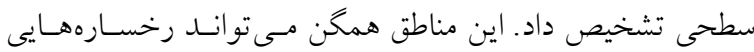
مانند مخروط افكنه، دشتسر، تِههاى ماسهاى و واحدهاى كـارى

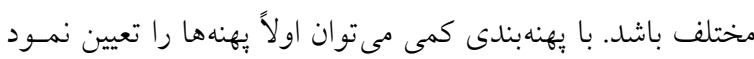

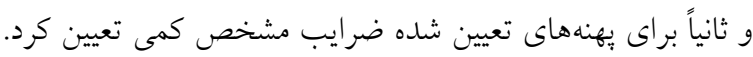
تشخيص بهنههـا بـهـورت كمى كـامهـاى بعـدى را در انجـام

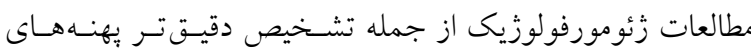

$$
\text { مناسب تغذيه مصنوعى اشاره كرد. }
$$

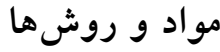

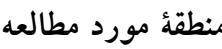

منطقه مورد مطالعه حوضه آبخيـز كربايخـان در مورد كيلـومترى جنوب شرق شيراز، در شهرستان فسا مسىباشـــ در بـين طـول

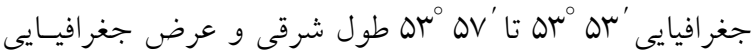

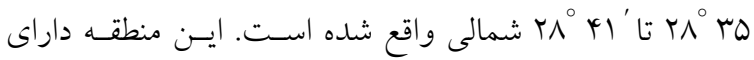

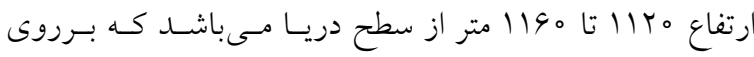

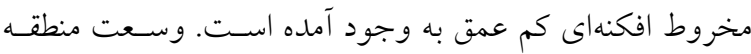

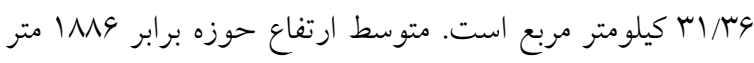

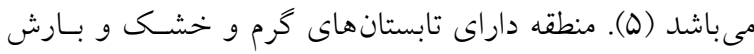

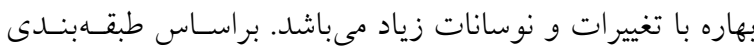

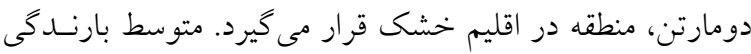

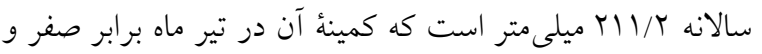

طبقهبندى خودكار استفاده مى گردد (IV). همجنـسين در بعضى از

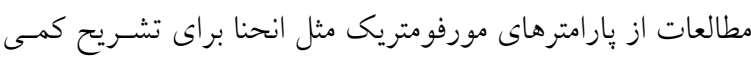

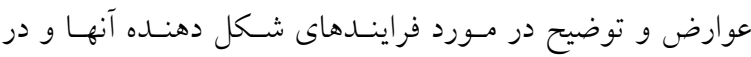

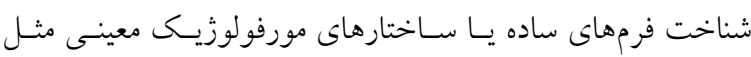

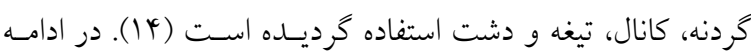

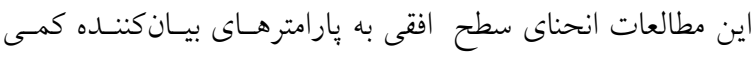

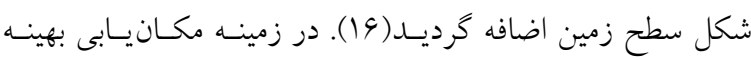

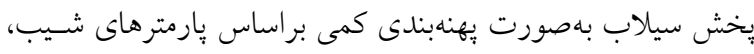

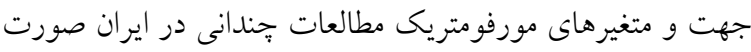

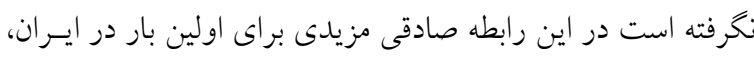

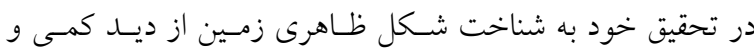

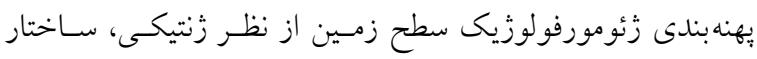

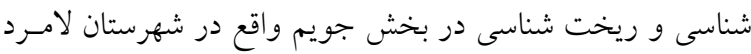

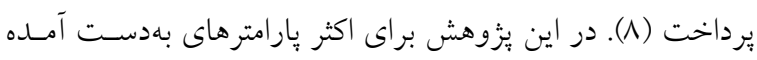

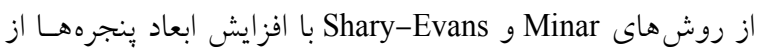

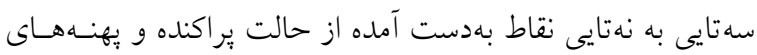

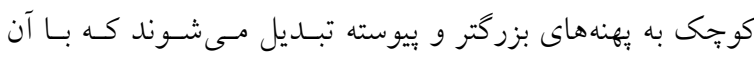

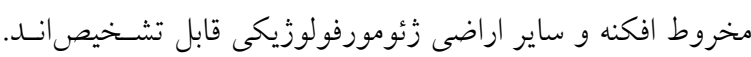

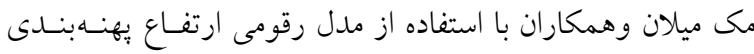

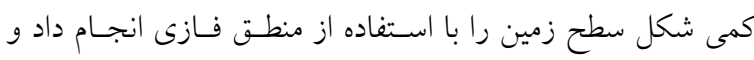

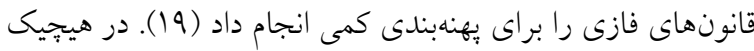

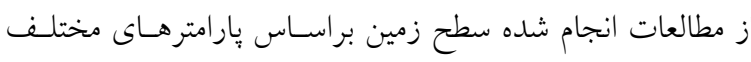

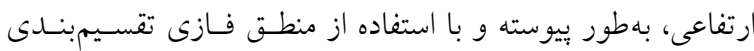

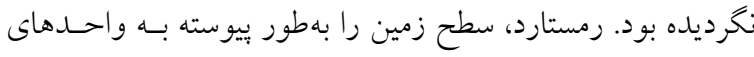

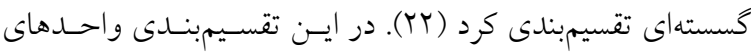

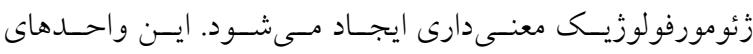

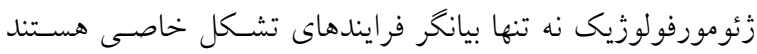

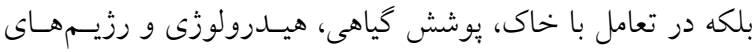

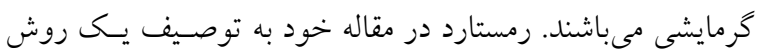

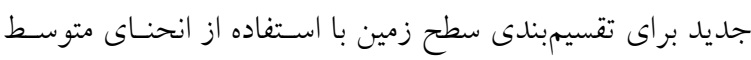

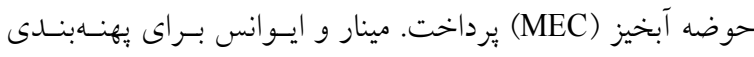

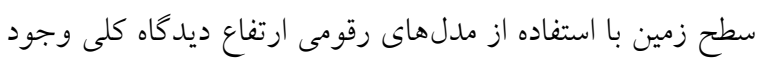



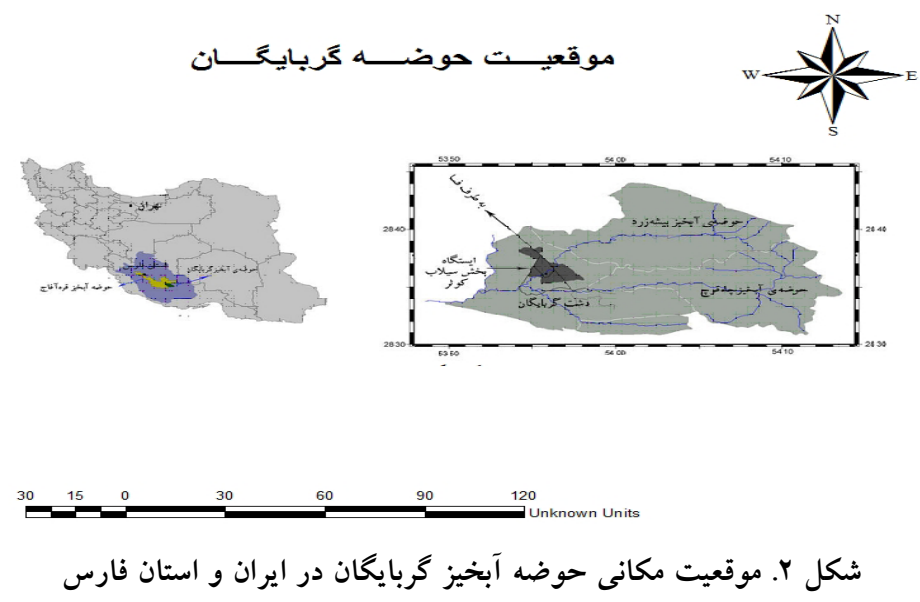

ويزگ گهى ماى مناطق مستعد بخش سيلاب

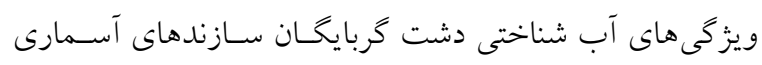

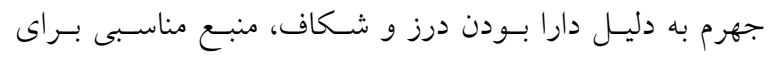

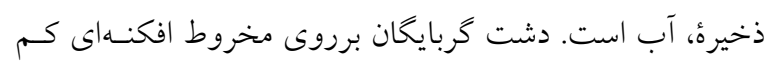

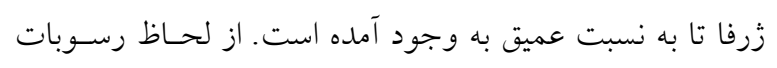

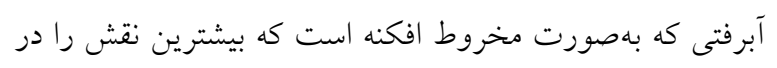

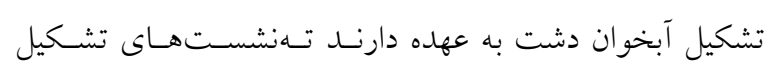

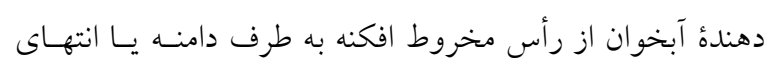

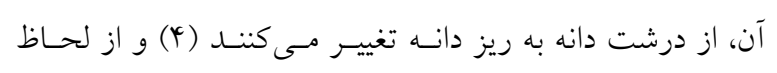

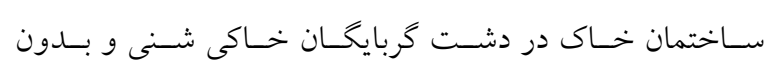

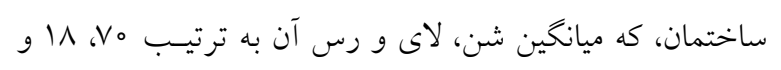

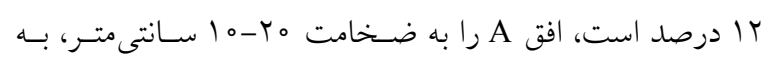
وجود آورده است. افق سنكى و سنكر يزهاى C مستقيماً در زيـــ

$$
\text { روش A Aرار كرفته است (11). }
$$

در اين مطالعه ضرايب مورفومتريكى اوانسـ - شـرى بـراى هـر

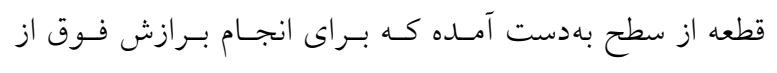

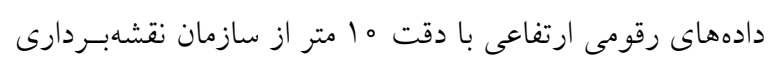

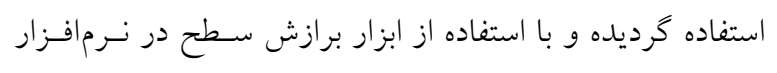

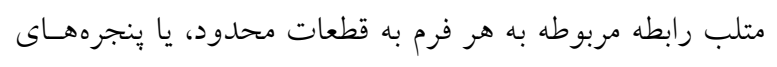

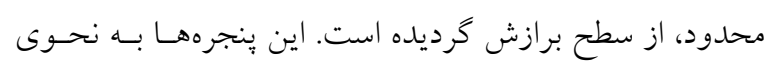
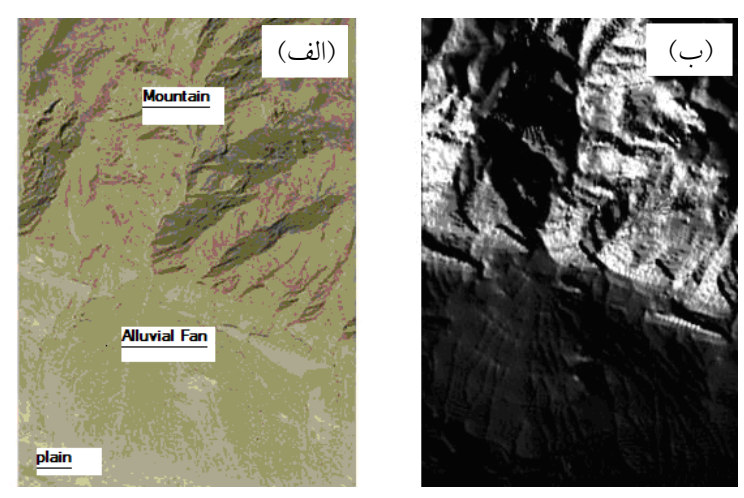

شكل (. الف) تصوير منطقه در گو گل ارث، ب) نمايش شيب در

\section{جهت محور}

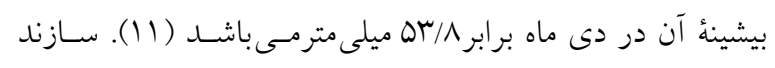

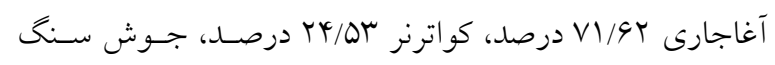

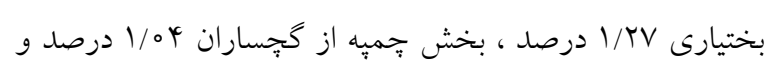

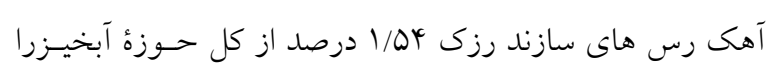

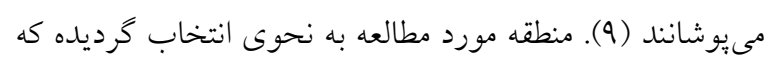

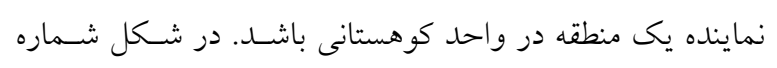

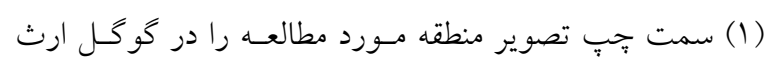

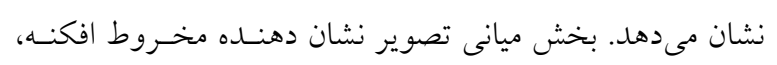

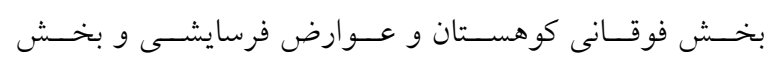

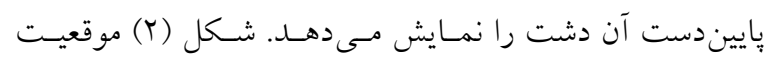
منطقه در ايران و استان فارس را نشان مي دهد. 
جدول ا. يارامتر معرفى شده توسط اوانس - شرى به همراه تعريف و رابطه آن

\begin{tabular}{|c|c|c|}
\hline متغير & ت تعريف & فرمول \\
\hline $\mathrm{kv}_{\mathrm{s}}$ & انحناى سطح در جهت عمود بر خط كتتورى & $\mathrm{kv}_{\mathrm{s}}=\left(\mathrm{p}^{r} \mathrm{r}+r \mathrm{pqs}+\mathrm{q}^{r} \mathrm{t}\right) /\left[\left(\mathrm{p}^{r}+\mathrm{q}^{r}\right)\left(1+\mathrm{p}^{r}+\mathrm{q}^{r}\right)^{r / r}\right]$ \\
\hline
\end{tabular}

جدول r. ضرايب معرفى شده توسط اوانس - شرى به همراه فرمول و رابطه آن

\begin{tabular}{|c|c|c|}
\hline 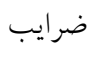 & روابط & 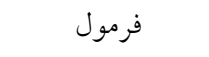 \\
\hline $\mathrm{p}_{\mathrm{s}}$ & $\left(\mathbf{Z}_{r}+\mathbf{Z}_{\varphi}+\mathbf{Z}_{\varphi} \mathbf{Z}_{\uparrow} \mathbf{Z}_{\varphi} \mathbf{Z}_{V}\right) / \varphi \mathrm{W}$ & $\mathrm{p}_{\mathrm{s}}=\partial \mathrm{z} / \partial \mathrm{x}$ \\
\hline $\mathrm{q}_{\mathrm{s}}$ & $\left(\mathbf{Z}_{\uparrow}+\mathbf{Z}_{\curlyvee}+\mathbf{Z}_{\curlyvee} \mathbf{Z}_{\checkmark} \mathbf{Z}_{\wedge} \mathbf{Z}_{q}\right) / \varepsilon \mathrm{W}$ & $\mathrm{q}_{\mathrm{s}}=\partial \mathrm{z} / \partial \mathrm{y}$ \\
\hline $\mathrm{r}_{\mathrm{S}}$ & {$\left[Z_{1}+Z_{r}+Z_{\varphi}+Z_{\varphi}+Z_{V}+Z_{\varphi}{ }^{r}\left(Z_{r}+Z_{\Delta}+Z_{\curlywedge}\right)\right] / r W$} & $\mathrm{r}_{\mathrm{s}}=\partial^{r} \mathrm{z} / \partial \mathrm{x}^{r}$ \\
\hline $\mathrm{s}_{\mathrm{S}}$ & $\left(\mathbf{Z}_{1}+\mathbf{Z}_{r} \mathbf{Z}_{v}+\mathbf{Z}_{q}\right) /{ }^{r} \mathbf{W}^{r}$ & $\mathrm{~s}_{\mathrm{s}}=\partial^{r} \mathrm{z} / \partial \mathrm{x} \partial \mathrm{y}$ \\
\hline $\mathrm{t}_{\mathrm{s}}$ & 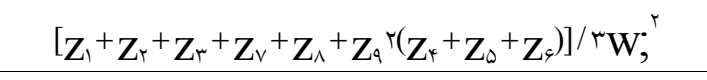 & $t_{s}=\partial^{r} z / \partial y^{r}$ \\
\hline
\end{tabular}

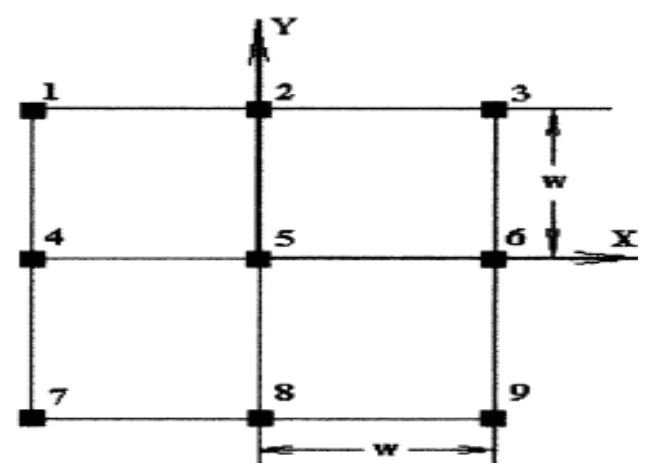

شكل r. موقعيت و تعداد داده هاى ارتفاعى براى ينجره س×r

ماتريس داده شده در شـكل بـالا نشـان داده شـوند (شـكل ؟)، مقادير مشتقهـاى ارائسه شــده در جــدول (Y) براسـاس مقـادير ارتفاعى داده شده در اين 9 نقطه براساس روابط ارائسه شـده در ستون Y جدول (Y) قابل محاسبه هستند.

حد مجاز مجموع مربعات ميانگين خطا در واقع جذر ميانخين مربـع اخـتلافهـاى بـين مقـادير ارتفـاع مشاهده شده و محاسبه شده در هر ينجره مىباشد. براى تعيسين حد قابل قبول براى RMSE از رابطة ارائه شده توسط مينار كـه در زير ارائه شده استفاده مىشود (Yo): $\mathrm{MF}=1-\kappa \mu /\left(\mathrm{O} * \tan \delta_{\mathrm{c}}\right)$

در اين رابطه Mf مقدار تابع عضويت يُنجره مورد نظر در مـدل
انتخاب مىشوند كه حالت مربعى داشته و مثلاً ابعاد آنها س×M و يا 9×9 باشد و با حركـت تنجــره در كـل محسدوده هـر يـك از يهنههاى ضرايب كمى زئومورفولوزيك حاصل مى گردد. درجسه. برازش و بارامترهاى فرم برازش شده براى تعيين مناسب بـودن قطعه براى بخش سيلاب اهميت استفاده يارامتر مجموع اختلاف مربعات اختلافات سطح زيادى دارد. براى تصميم گيـرى در ايسن مورد كه درجه برازش فرم كمسى بـهـ دادههـاى ارتفــاعى در هـــ ينجره از يارمتر شده است و از طريق اين يارامتر مناطق مناسـب براى يخش سيلاب نمايش داده شده است.

$$
\text { ضرايب اوانس - شرى }
$$

ضرايب اصلى اوانس و شرى كه به كمك آنها شيب، و انحناى سـطح در جهات اصلى تعيين مسى كـردد انحنـاى عمـودى مسىباشـند. ايسن ضريب kv نمايش داده مى شود (جدول (). براسـاس رابطـه ارائـه شده در جدول ( ) ضرايب اوانس و شرى براساس مشتقات ارتفـاع

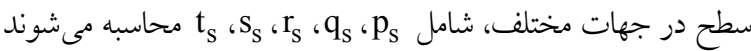
و روابط مربوط به مشتقها در جدول (T) آورده شده است. براى محاسبة مشتق هاى سطح در جهات مختلف مىبايست از دادههاى ارتفاعى موجود در هر ينجره استفاده گـــدد (شـكل

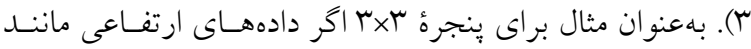


نقشه هاى زئومورفولوزى بهعنوان كروهـى از نقشسهـــاى مـورد

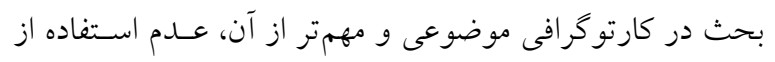

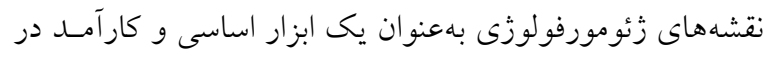

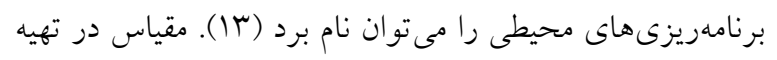

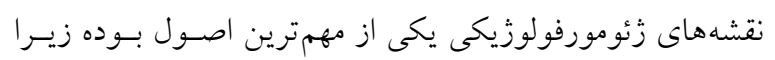

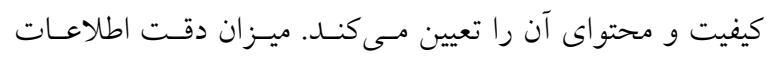

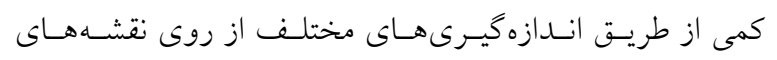

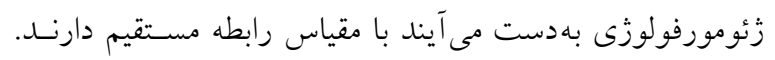

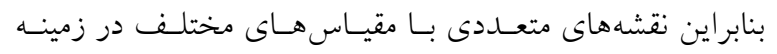

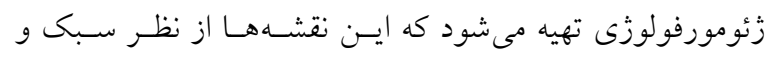

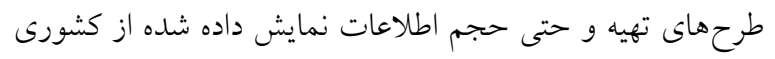

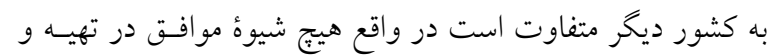

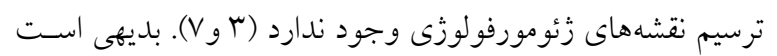

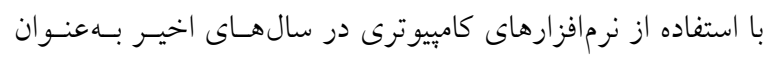

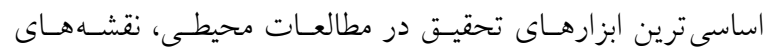

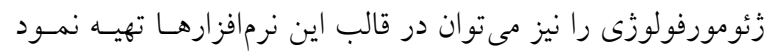

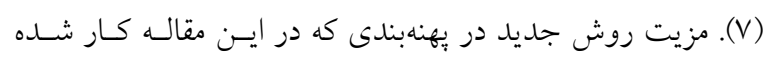

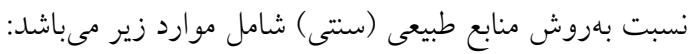

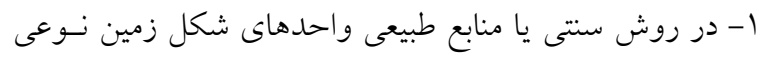

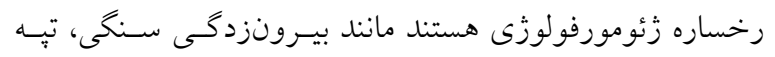

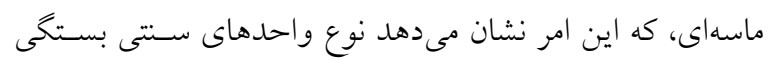

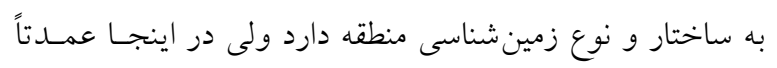

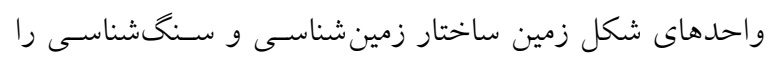

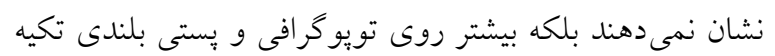

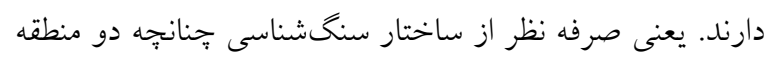

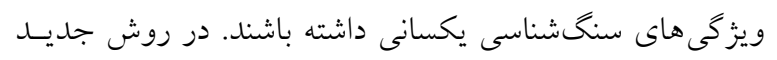

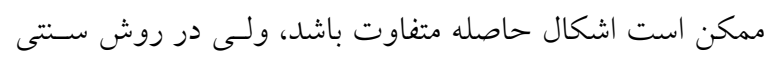

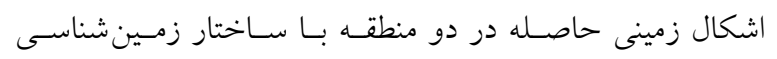
يكسان واحدهاى يكسان و مشابهى ارائه مى كنند.

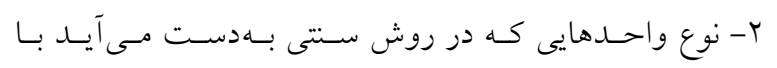
واحدهاى شكل زمين در اينجا متفـاوت بـوده و تعـداد اشـكال حاصله در روش جديد بيشتر و كاربردىتر است.
مربوطه، لم مقدار RMSE محاسبه شده از برازش انجـام شـده و

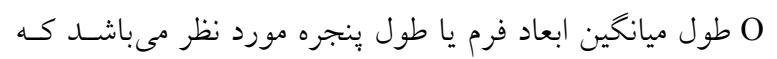

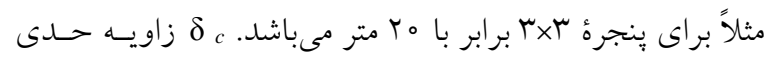

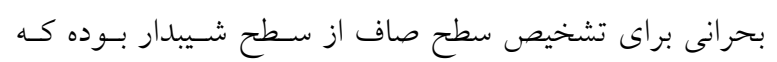

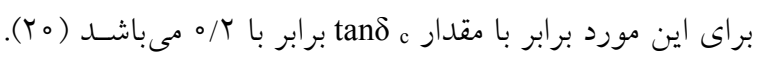

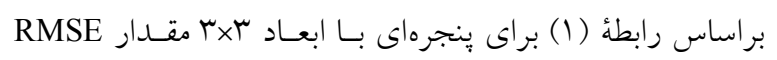

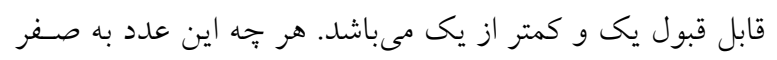

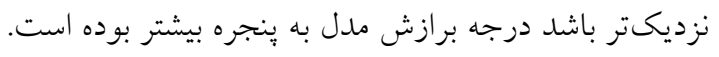

\section{بحث و نتايج}

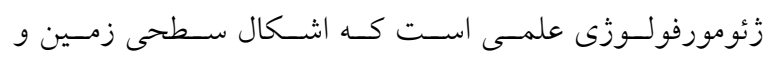

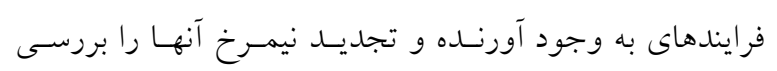

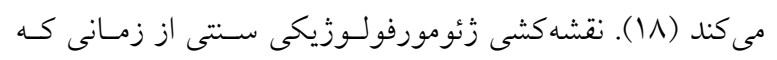

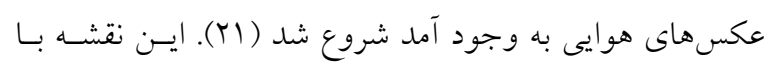

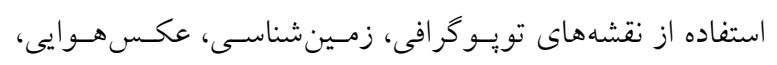

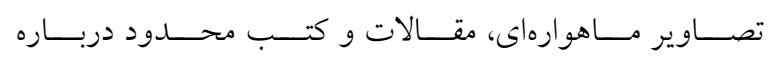
زئومورفولوزى و تا حدودى مطالعات روى زمسين تهيـهـ گرديسـ

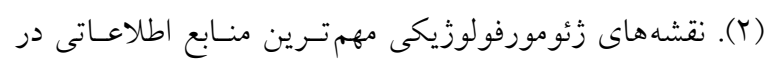

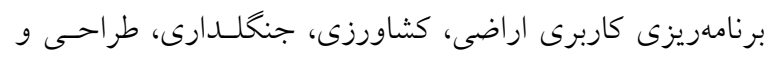

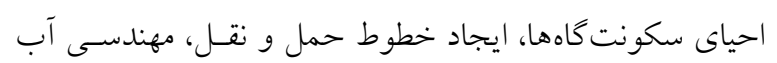

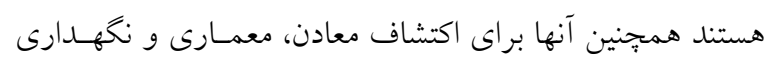

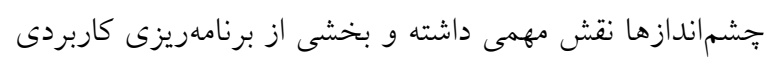

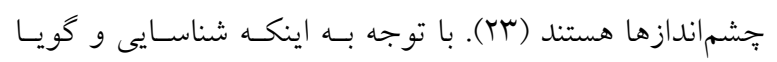

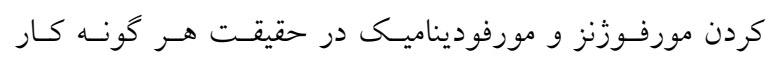

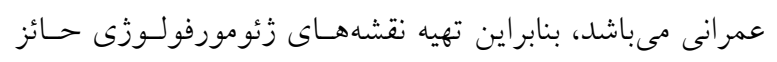

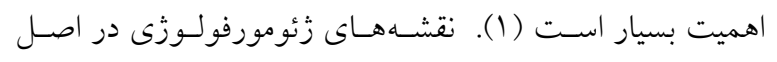

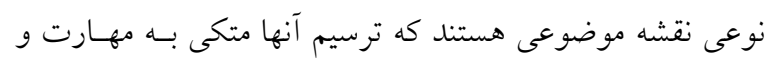

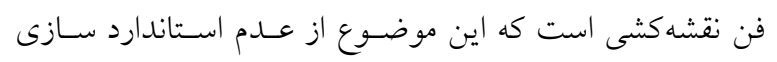

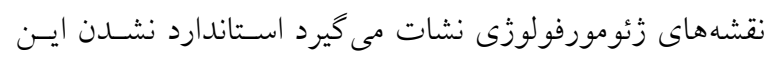

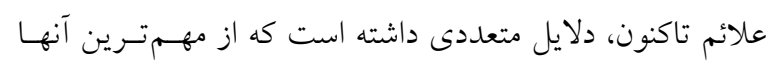

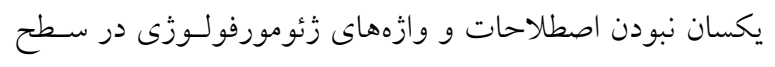

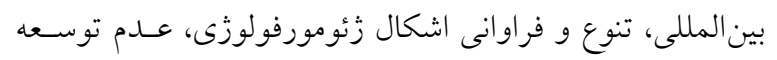




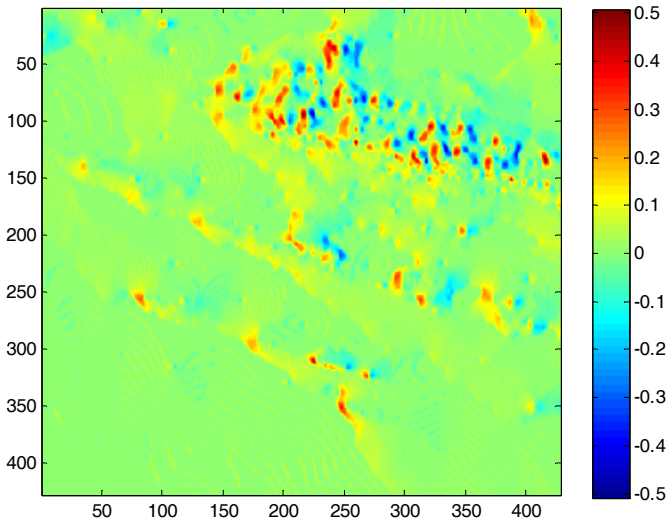

شكل ه. نقشهُ مقادير ضريب qs براى ينجره سهتايى

و براى دامنههايى كه رو به غرب و شرق هستند بيشترين مقادير مطلق را دارد. دامنههاى رو به غرب رنخ قرمـز و شـيب مثــت دارند و دامنههاى روبه شرق رنخ آبى و شيب منفى دارند. مـرز بين محدودههاى قرمز و آبى رنخ خـط الـراس و يـا خـط القعـر

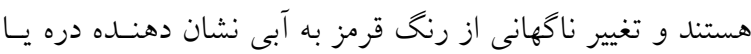
قله است و مخروط افكنها نيز در دو طرف داراى تغييـر رنــ از سبز به زرد هستند. برروى قسمتهاى قرمز رنخ نيز حالـت ناهموارىهايى بهصورت تناوب زرد و قرمز مشاهده مىشود كه نشان دهنده زبر بوده سطح مىباشد. از لحاظ مناسبترين مناطق براى يخش سيلاب سـطوح مقعـر كـه داراى جريـان همخــا و و داراى قابليت جمع كـردن آب مسىباشـــ بــراى بخـش سـيلاب مناسبتر است. qx انحناى شيب در جهت عمود بر شيب اصلى دامنه است(شكل ه). در اين شـكل دامنـههـاى جنـوبى داراى مقادير مثبت مىباشد كه بيشترين مقادير اين ضريب در حاشسيه شمالى حوضهاى فرسايشى كوهگر مشاهده مى شود دامنههـاى روبه شمال، رنخُ آبى تيره داشته كه داراى دامنهاى منفى و بــه حالت تقعر بوده و آب را متمركز كرده يا جمع مىنمايند و براى يخش سيلاب مناسب هستند. rs اين ضريب تغييـرات شـيب در جهت شرق مىباشد (شكل 9). اين شكل مقـادير مثبـت نشـان دهنده تقعر سطح در جهت شرق بـه غـرب و مقـادير منفـى آن نشان دهنده تحدب سطح در جهت شرق به غرب است. جنانكه

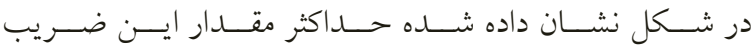

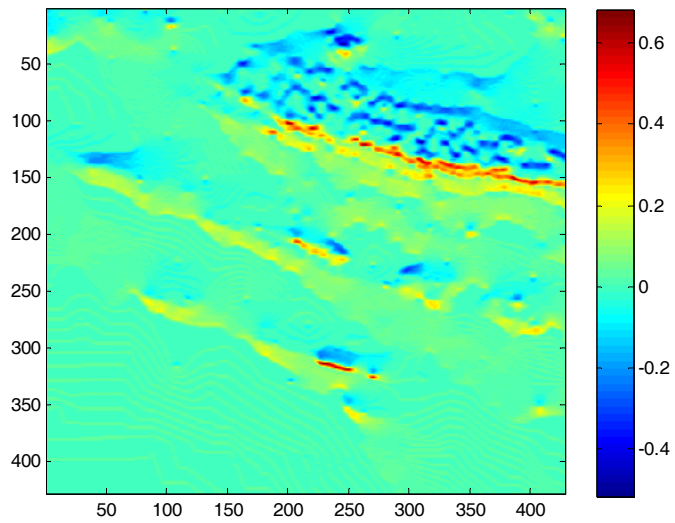

شكل fا. نقشهُ مقادير ضريب ps براى ينجره سهتايى

ץ- در روش سنتى (كه منابع طبيعى در ايران اسـتفاده مسىكنـد) نقشهها غيرديجيتالى است ولى در اين روش نقشههاى تهيه شده

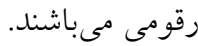

ץ- در بهنه بندى كمى سليقه و درجه مهارت كارشـناس دخيـل نيست و با استفاده از راهكارهاى كمى مشخص، بيهنه ها به دست خواهند آمد از طرف ديخر يهنه هاى مشخص شده بـا روابـط و ضر ايبى مشخص مى شوند كه تغييرات ايسن ضـرايب در منـاطق مختلف براى مقايسه بيهنها قابل استفاده مىباشد (YY).

$$
\text { ضر ايب كمى ايوانس - شرى }
$$

به تغيير شيب در جهت هاى مختلف اشكال شيب مى گوينـد. در اين تحقيق تغييرات شيب در جهات محور افقى، محور عمودى، شرق، شمال شرقى و غرب كه به ترتيـب بـا pـ ابعاد ينجرههاى سهتايى در محسـدوده حوضـه آبخيـز كربايخـان برازش شده كه به ترتيب در شكلهاى زير نشان داده شده است

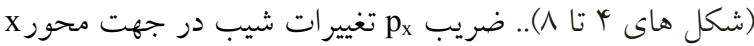
مىباشد. كه در واقع بيانكر انحناى شيب در جهت اصلى دامنسه. از قله تا بِاى شيب مىباشد و تحدب و تقعر دامنه در جهت بالا و يايين دامنه را نشان مسىدهـد (شـكل †). در منـاطق دشـتى و ياييندست مخروط افكنهها مقادير ضريب فوق نزديك به صـفر بوده و در محدودهُ كوهستانى مقادير آن از صفر دور است. ايسن يارامتر نشان دهنده شيب منفى يا مثبت در جهت محور X بـوده 


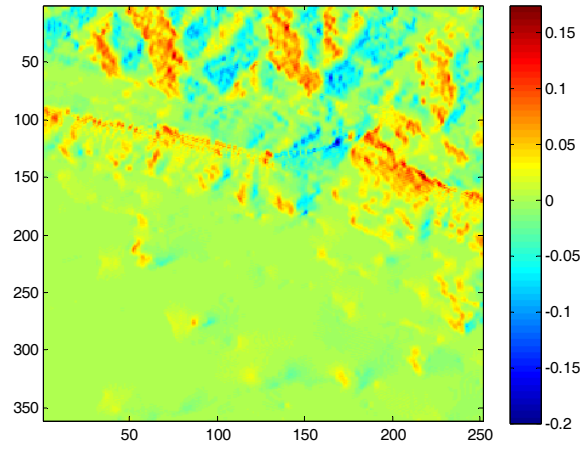

شكل V. نقشُ مقادير ضريب Ss براى پنجره سهتايى

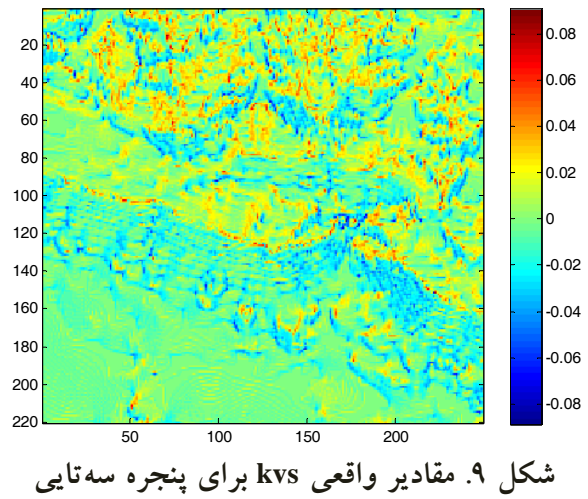

به منطقه كوهستانى دارند با رنخ سبز نمايش داده شدهاند.

متغير اوانس - شرى( ضريب kvs براى ينجره سهتايى) اين ضريب از بارامترهاى مهم در زئومورفولوزى است و بيانگر خط حركت جريان آب مى باشد. اخر اين ضـريب مثبـت باشـــ داراى انحناى طولى يا انحناى عمودى محدب بـوده و سـرعت جريان آب در آن افزاينـده اسـت ضـريب منفـى داراى انحنــاى طولى مقعر و سرعت جريان آب در آن كاهنده مىباشد بهتـرين كلاس انحناى عمودى براى بخش سـيلاب كـلاس كـو جكتر از صفر است كه علت آن اين است كه سطح، آب را در اين حالت جمع مى كند و كمترين تناسب بـراى انحنـاى عمـودى كـلاس بزركتر از صفر براى بخش سيلاب مىباشد (شكل 9). طبق اين

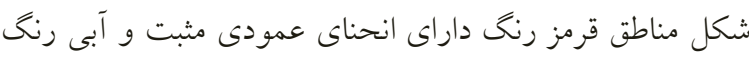
داراى انحنا منفى هستند براى مخروط افكنه بافت خاصى بـراى انحناى عمودى وجود دارد. كف دشت فاقد انحنا بـوده و داراى

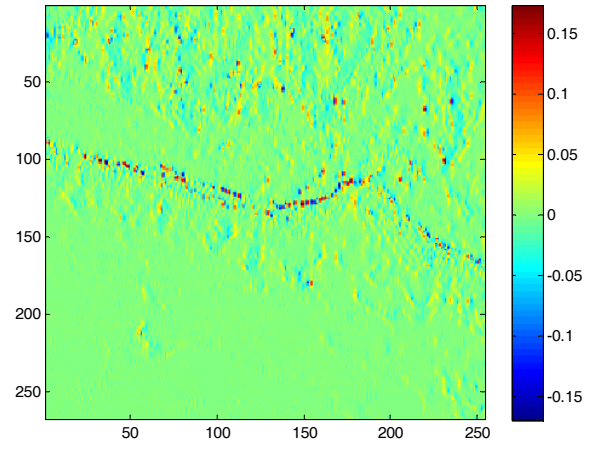

شكل q. نقشهُ مقادير ضريب rs براى ينجره سه تايى

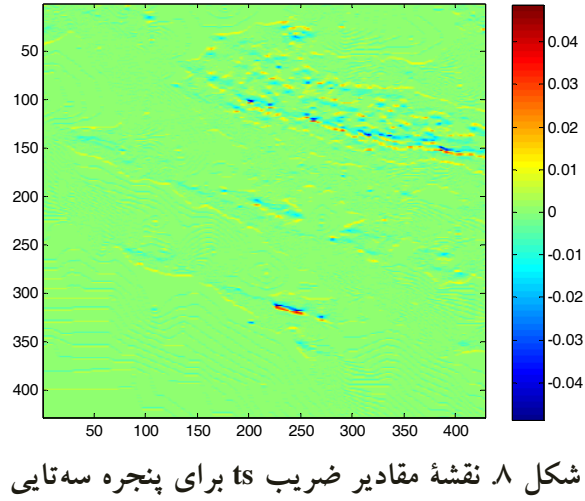

برروى حواشى منطقه فرسايشى يا حاشيه حوضه آبريز بالادست مخروط افكنهها مىباشد كه داراى شيب تند بـوده و بــا تنـاوبـ رنخهاى آبى، زرد و قرمز نمايش داده شده است. حداقل مقدار اين ضريب روى مناطقى كه يُتى و بلندى كمتـرى نسـبت بـه منطقه كوهستانى دارند وجود دارد و با رنخ سبز نشان داده شده است.ضريب SS تغييرات شيب در جهت شمالشـرقى مسىباشــ (شكل V). طبق اين شكل زمانى اين ضريب مثبت است كـه يـا شيب غالب سطح در جهت شمال غربى يا جنوب شرقى بوده و سطح محسـب باشــ، و يـا شـيب در جهـت شـمالشـرقى يـا جنوبغربى بوده و مقعر باشد. ضريب ts در واقع تغييرات شيب در جهت غرب مىباشد (شـكل ^).. طبـق ايـن شـكل حـــاكثر مقدار اين ضريب برروى حواشى منطقه فرسايشى يا حوضههاى

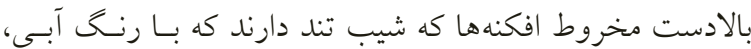
زرد و قرمز متناوب نمايش داده شده است قــرار دارد و حــداقل مقدار اين ضريب روى مناطقى كه يستى و بلندى كمترى نسبت 
نيست و با استفاده از راهكارهاى كمى مشخص، يهنه ها بهدست

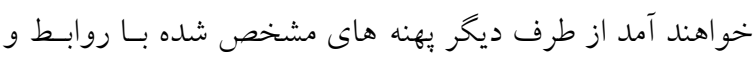

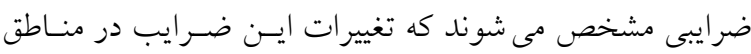

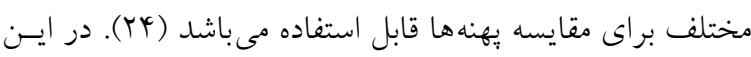

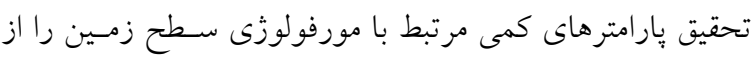

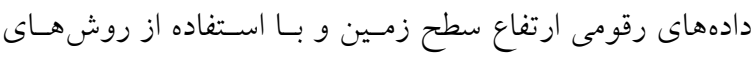
عددى و بدون استفاده از خصوصيات منطقه تعيين كرد. در ايسن روشها با انتخاب دادههاى رقومى ارتفاع مربوط به به يك يبكسل

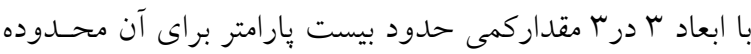

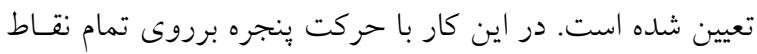

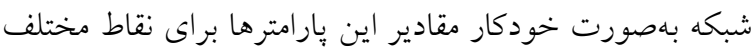

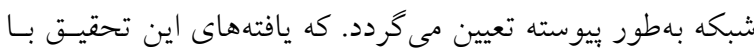

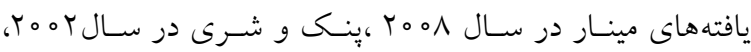

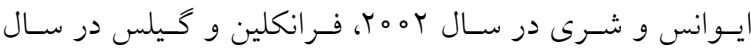

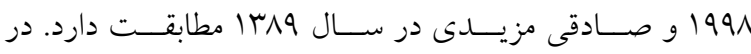

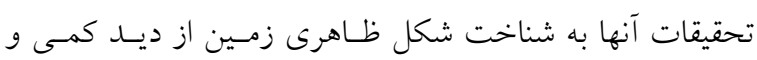

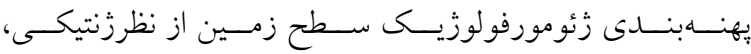
ساختارشناسى و زئومورفولوزى يرداختند. يكى ديخر از اهـــاف

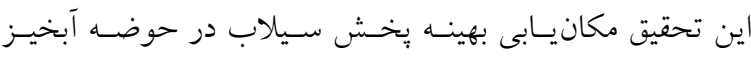

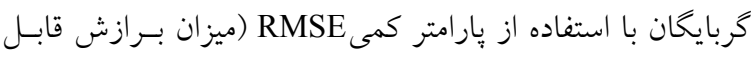

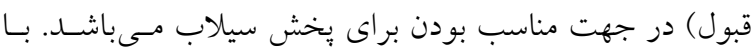

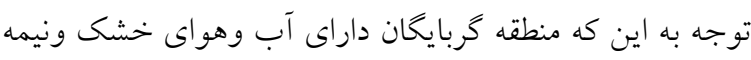

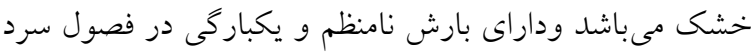

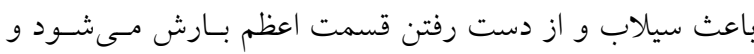

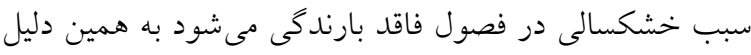

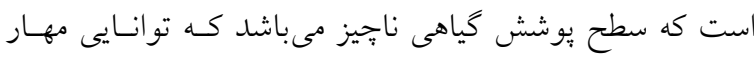

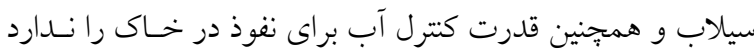

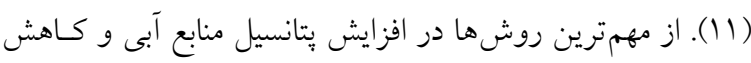

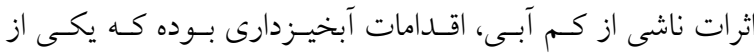

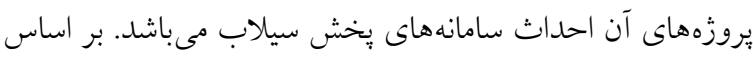

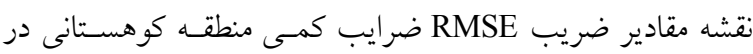

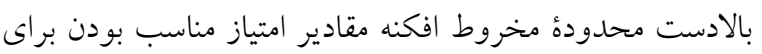

مقدار صفر مى باشد. مشاهده مى شود كه در مناطق كوهستانى و

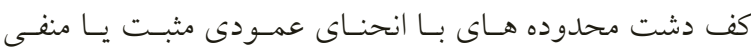

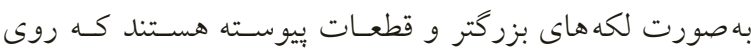

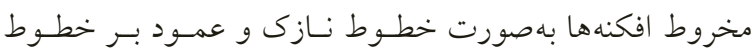

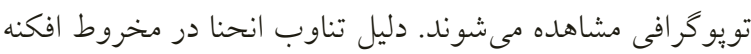

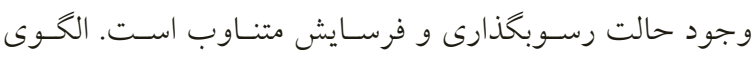

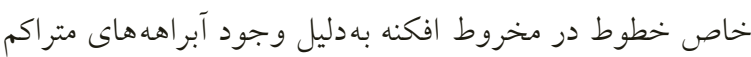

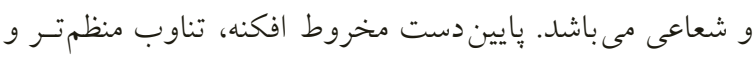

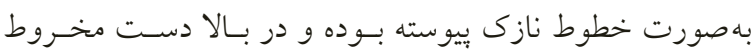

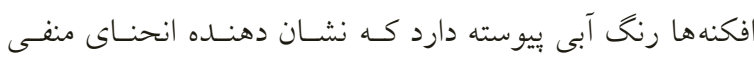
(مقعر) مى باشد.

\section{نتيجه گيرى}

با توجه به توسعه روز افزون بهـرهبــردارى از منـابع در مبحـث

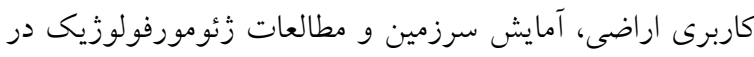

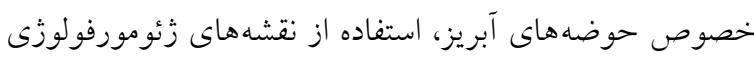

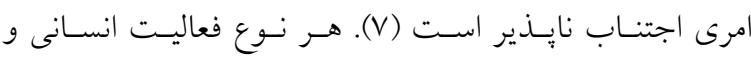

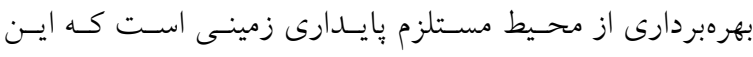

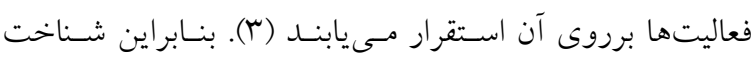

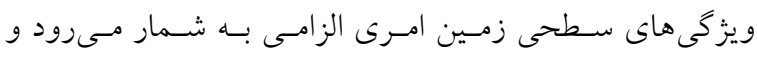

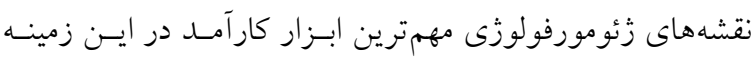

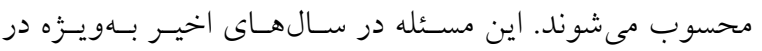

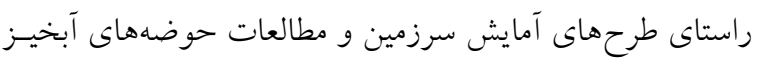

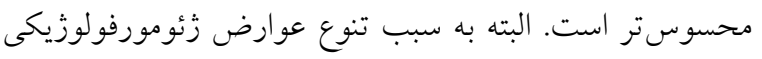
و تنوع نقشهها از نظر مقياس و متفاوت بودن روش تهيه هنـوز

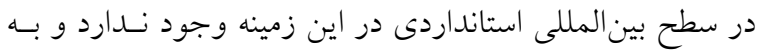

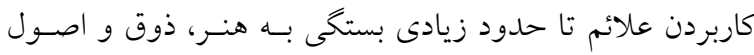

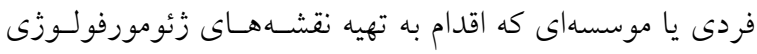

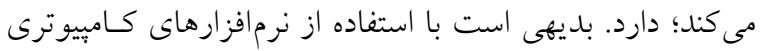

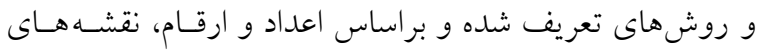

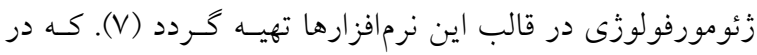

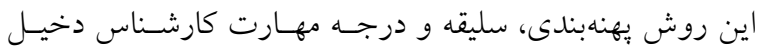


خيلى مناسب هستند در وسط و كلاسهـاى ديخـر بـه ترتيـب

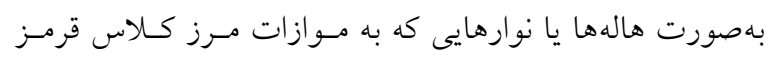

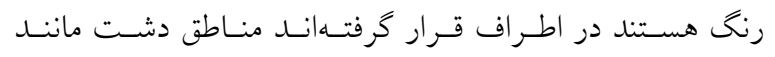

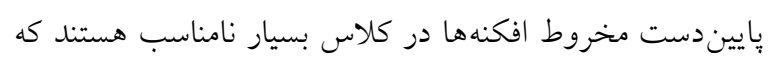

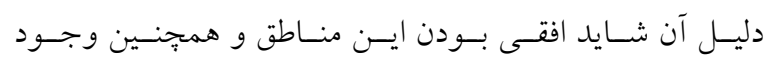

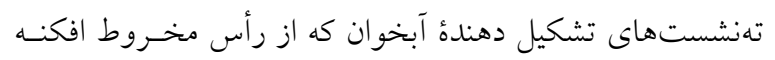

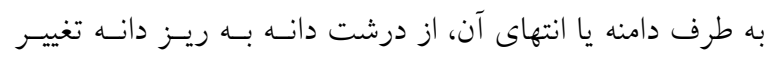

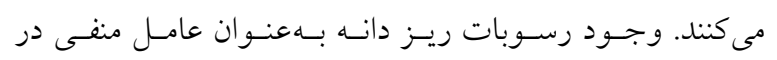

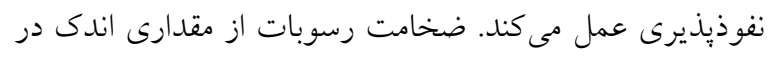

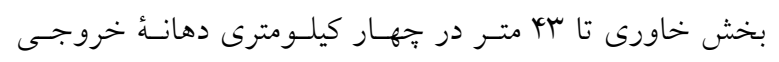

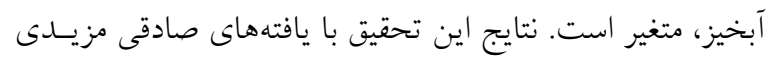

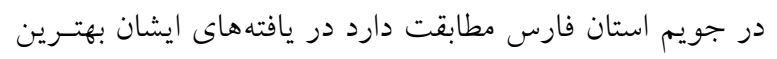

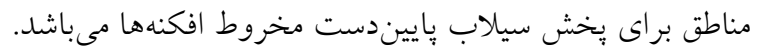

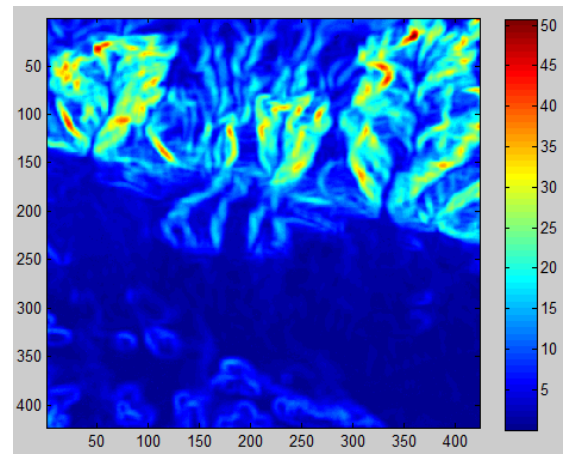

شكل ه 1. نقشهُ مقادير ضريبRME براى ينجره سهتايى

تغذيه مصنوعى نزديك به صفر بوده و با رنخ آبى تيره نمـايش

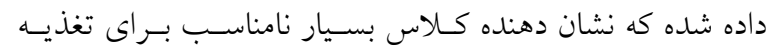

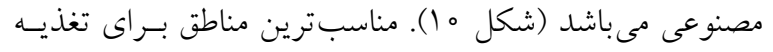

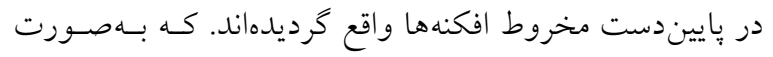

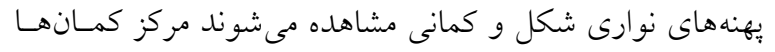

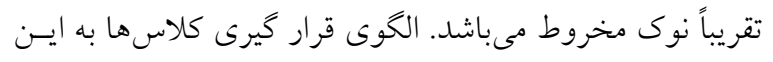

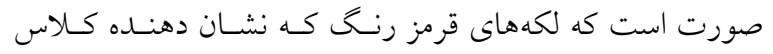

\section{منابع مورد استفاده}

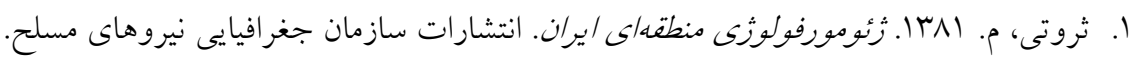

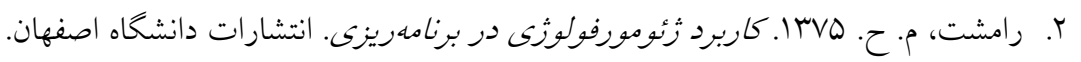

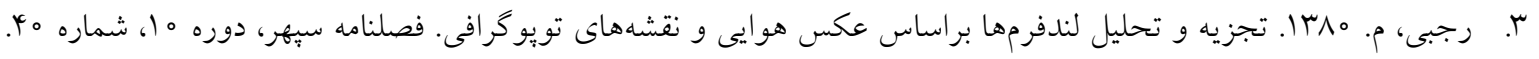

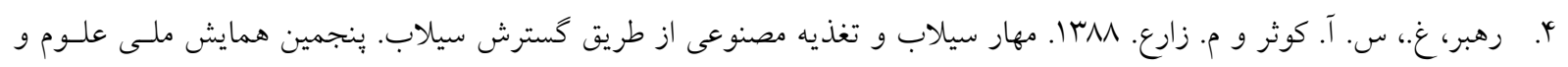

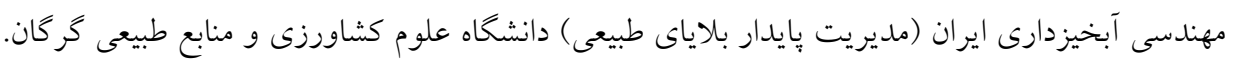

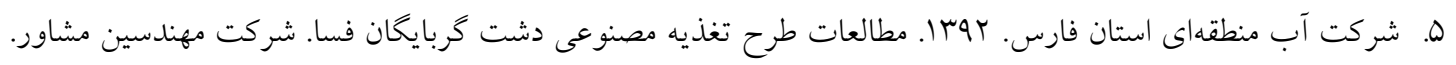

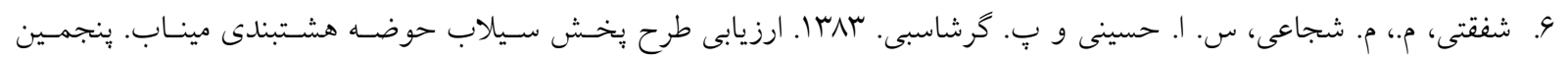

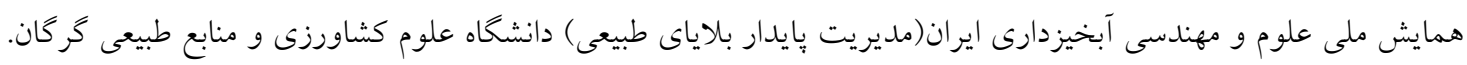

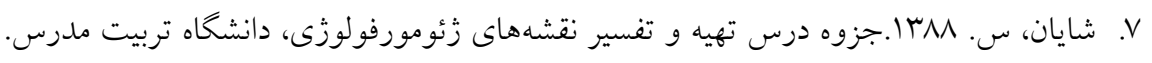

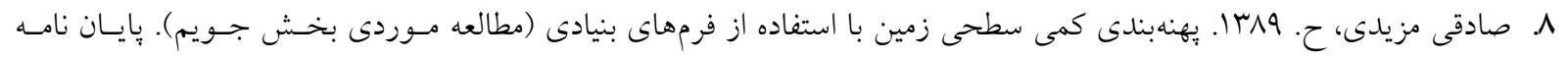

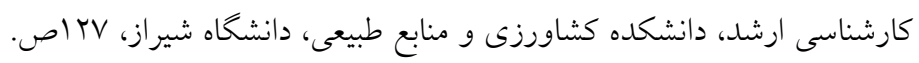

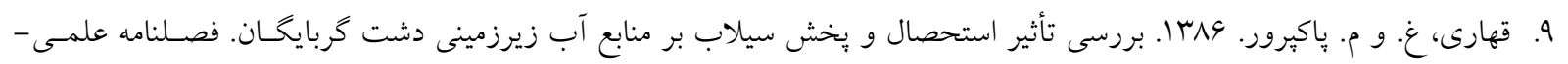

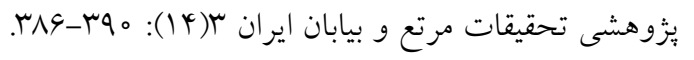

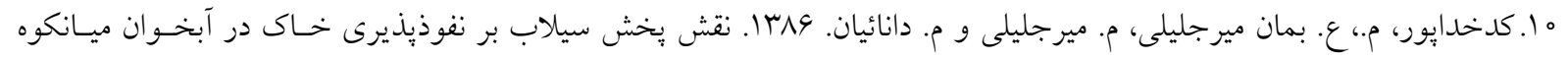

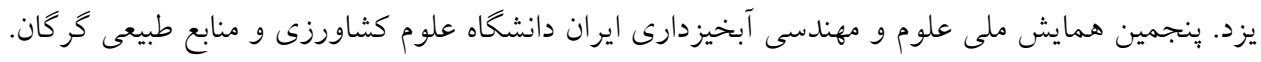




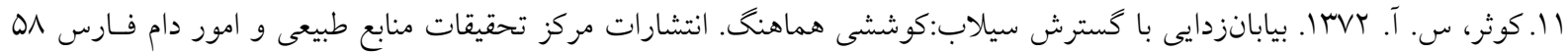

$$
\begin{aligned}
& \text { صفخه. }
\end{aligned}
$$

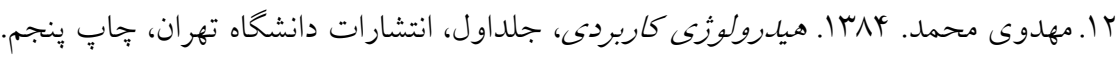

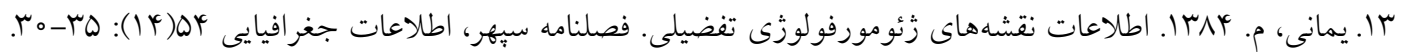

14. De Graff, L.W.S., M. G. G. De Jong, J. Rupke and J. Verhofstad. 1987. A geomorphological mapping system at scale 1:10,000. Zeitschrift für Geomorphologie N.F. Supplementband 31: 229-242.

15. Dikau, R. 1989. The application of a digital relief model to landform analysis ingeomorphology. pp. 51-77. In: Raper, J. (Ed.), Three-dimensional Applications in Geographical Information Systems. Taylor \&Francis, London.

16. Evans, I. S., N. J. Cox. 1999. Relations between land surface properties: altitude, slope and curvature. pp. 13-45. In: Hergarten, S.,Neugebauer, H. J. (Eds.), Process Modelling and Landform Evolution. Springer, Berlin.

17. Giles, P. T., S. E. Franklin. 1998. An automated approach to the classification of slope units using digital data. Geomorphology 21: 251-264.

18. M., E. Kolstrup and A. C. Seijmonsbergen. 2006. A new symbol-and-Gis based detailed geomorphological mapping system: Renewal of a scientifc discipline for understanding landscape development, Geomorphology 77:90-111.

19. MacMillan, R. A., W. W. Pettapiece, S. C. Nolan and T. W. Goddard. 2000. A generic procedure for automatically segmenting landformsinto landform elements using DEMs Heuristic rules and fuzzy logic. Fuzzy Sets and Systems 113: 81-109

20. Minár, J., I. S. Evans. 2008. Elementary forms for land surface segmentation: the theoretical basis of terrain analysis and geomorphological mapping. Geomorphology 95: 236-259.

21. Oya, Masahico. 1983. A geomorphological survey map padang city and surrounding area in west Sumatra showing classifcation of food stricken areas, International Cooperation Agency,Tokyo, Japan.

22. Romstad, B. 2001. Improving relief classification with contextual merging. In: Bjørke, J. T., Håvard, T. (Eds.), Proceedings of the 8th Scandinavian Research Conference on Geographical Infor- mation Science. ScanGIS'2001, 25th-27th June 2001.

23. Rao, D. P. 1978. Utility of Landsat coverage for small scale geomorphological mapping- some example from India, J. Ind. Soc. of Photointerpretation 6(2): 49-56.

24. Shary, P. A. 1995. Land surface in gravity points classification by a complete systemof curvatures. J. Mathematical Geology 27(3): 373-390. 


\title{
The Quantitative Zoning of Ground Surface by Quantitative Coefficients for Positioning the Optimal Flood Spreading (Case Study: Fasa Garebayegan Catchment)
}

\author{
S. Ebrahimiyan ${ }^{1^{*}}$, M. Nohtani ${ }^{* *}$ and H. Sadeghi Mazidi²
}

(Received: Jan. 06-2015 ; Accepted: May 31-2016)

\begin{abstract}
The basis of spatial planning is the geomorphological zoning of ground surface, in which the first phase is determining the homogeneous zones of the ground surface in terms of geomorphological characteristics. The current study aimed at determining the proper zones for artificial feeding in Gahar mountainous region and Garebayegan plains in Fars province by the use of zoning the ground by Evans-Chezy quantitative coefficients. The quantitative zoning of ground surface plays a vital role in more accurate determination of the land capabilities due to precise determination and division of the types, facies, and surface terrains. For this study, the elevation numeral data with 10m resolution obtained from the National Cartographic Center was used. By the use of surface fitting tools in MATLAB software, the equation for each form was fitted to limited fragments of the surface and the program was applied. Then, each of the quantitative coefficients was illustrated as some zones. For determination of fitting degree, the total squared difference between the rate parameter was used and by the use of fitness degree, the propriety degree of the surface for optimal positioning of flood spreading with surface morphological view was determined. The results indicate that the surface downstream the alluvial fans and plains located on the southern region of the studied land is the most appropriate zone for the Flood Spreading. This area constitutes a surface of $10 \%$ of the total area of the region.
\end{abstract}

Keywords: Evans-Shary, Geomorphological quantitative zoning, Flood spreading, Garebayegan.

1. Dept. of, Range and Watershed Managemen, College of Water and soil, Univ. of Zabol, Zabol, Iran.

2. Dept. of, Watershed management, College of Agric. and Natural Resour., Univ. of Hormozgan, Hormozgan, Iran.

*: Corresponding Author, Email: m_nohtani@yahoo.com 